\title{
An Empirical Assessment of Marine Debris, Seawater Quality and Littering in Ghana
}

\author{
Irene P. Van Dyck ${ }^{1}$, Francis K. E. Nunoo², Elaine T. Lawson'1 \\ ${ }^{1}$ Institute for Environment and Sanitation Studies, University of Ghana, Accra, Ghana \\ ${ }^{2}$ Department of Marine \& Fisheries Sciences, University of Ghana, Accra, Ghana \\ Email: rinihimans@yahoo.co.uk, fkenunoo@ug.edu.gh, elaine_t@ug.edu.gh
}

Received 22 March 2016; accepted 3 May 2016; published 6 May 2016

Copyright @ 2016 by authors and Scientific Research Publishing Inc.

This work is licensed under the Creative Commons Attribution International License (CC BY).

http://creativecommons.org/licenses/by/4.0/

(c) (i) Open Access

\begin{abstract}
A baseline survey was carried out at four beaches along Ghana's Accra-Tema coastline over a period of sixteen weeks to determine beach quality, seawater quality and the perception of beach users towards littering. A total of 18,241 items of marine debris which weighed $297.59 \mathrm{~kg}$ were collected. Plastic materials were the dominant debris, accounting for $63.72 \%$ of total debris. Landbased marine debris formed the largest proportion of debris collected $\left(93 \%\right.$ of items $/ \mathrm{m}^{2}$ and 85 $\mathrm{kg} / \mathrm{m}^{2}$ ). Water quality analysis revealed high mean levels of coliforms and $E$. coli above World Health Organization (WHO) levels on all four beach locations. A social survey that targeted beach users and some stakeholders revealed a habit of littering and beach users as the main source of litter generation on Ghana's beaches. Intensive education, continuous monitoring and the enforcement of appropriate policy initiatives remain vital to addressing beach and water quality issues along Ghana's coastline.
\end{abstract}

\section{Keywords}

Marine Debris, Accra-Tema Coastline, Ghana, Plastics, Seawater Quality, Littering Perception

\section{Introduction}

Coastal areas form an important interface between land and sea. Although they cover only $10 \%$ of the earth's land area, they are home to over $60 \%$ of the world's population [1] [2]. Marine debris is defined as any manmade object discarded, disposed of, or abandoned that enters the coastal or marine environment [3]-[5]. Marine debris affects coastal areas and the sea floor at all depths [2] and has been described as one of the most pervasive pollution problems plaguing the world's oceans and waterways. It has been described further as an environmental, economic, health and aesthetic problem [4]-[7]. According to [4], marine debris can be derived from either 
ocean/waterway-based sources or land-based sources. Land-based sources account for about $80 \%$ of the world's marine pollution and the remaining $20 \%$ is credited to ocean/waterway-based sources [7]-[10]. Other items which cannot be traced to a specific or sole source are classified as general source items [11].

Ghana, a West African country with Accra as its capital, has a coastline of about $550 \mathrm{~km}$ facing the Gulf of Guinea [12]. The coastal zones are very productive representing a huge natural and economic resource for the country [13]. With an estimated population of 3 million people living along Accra's coast, there exists a major challenge in managing waste especially solid waste in metropolitan areas. Plastics form the most dominant type of litter [14]-[17]; an observation consistent with research findings worldwide: the Black Sea (82.53\%), the Indian Ocean (69.99\%), North Sea (65.79\%), Wider Caribbean (64.27\%), the Pacific Ocean (62.95\%) and Central Europe reporting the lowest plastic percentage with 42.79\% [5] [18].

Marine debris is especially evident on beaches after rains and during low tides posing a threat to the booming tourist industry in Ghana [17]. Faecal deposits also frequently occur, especially in areas where the adjacent communities do not have adequate toilet facilities. With tidal cycles, these deposits are washed into the sea and degrade the quality of the water. There is also direct sewage disposal into the sea [19] which can cause health hazards to both the users of the beach and sea biota. Ghana has ratified the International Convention for the Prevention of Pollution from Ships (MARPOL) (1973) and the Convention on the Prevention of Marine Pollution by Dumping of Wastes and other Matter (1972); the two primary international conventions that address waste and pollution in general and in the oceans by ships. Management practices that have been adopted along Ghana's coast include education, provision of collection, disposal and treatment infrastructure, recycling and beach cleanups [5]-[7] [17] [20].

Data on continuous monitoring and litter quantification are lacking in Ghana. The majority of scientific studies on marine debris in Ghana have addressed the type and quantities [11] [21]. Classification of debris as land or ocean-based is lacking. The duration of studies conducted on marine debris and water quality by other authors have been extremely short with an average of three weeks. This time duration is thus too short to provide a reliable outlook. Again, no social survey was carried out in any of these studies. People are the social drivers of the littering problem and it is therefore necessary for the people causing it to recognize this by coming to the realization that they contribute to it [22] [23].

Despite measures to prevent and reduce marine debris, evidence shows that the problem continues and will likely worsen. Some debris will continue to arrive on shores over the course of the next decade and beyond and will continue to pose some degree of risk to safety, environment and economy [3] [24]. Successful management of the marine debris problem requires a comprehensive understanding of the issue, including identifying the dominant forms of marine debris, their abundance, potential sources and activities producing the debris. Monitoring of marine debris will provide significant insight and understanding into the problem and can function as an ongoing component of management strategies. Monitoring activities can be used to assess the effectiveness of management strategies, legislation, and other activities designed to control and abate this pollution problem [4] [25] [26].

This study will therefore seek to (1) determine quantity and types of debris on the beaches, (2) distinguish litter collected as either land or ocean-based marine debris, (3) establish the spatial and temporal abundance of the marine debris, (4) determine the seawater quality in the designated locations along the Accra-Tema coastline by examining the total and faecal coliforms, and E. coli levels, and (5) evaluate public attitudes, perceptions and opinions about beach litter and other beach management issues.

\section{Materials and Methods}

\subsection{Study Areas}

The sites chosen for the study were the Sakumono beach, La Pleasure beach, Mensah Guinea beach and Korle Gonno beach (Figure 1). The distance between La Pleasure beach and Sakumono beach is about $9.7 \mathrm{~km}$. That of La Pleasure beach to Mensah Guinea beach is $7.1 \mathrm{~km}$ and from Mensah Guinea beach to Korle Gonno beach is $3.5 \mathrm{~km}$. These beaches were selected because they form part of the major coastline of Ghana and experience high interaction with coastal folks. Additionally, they have differing socio-economic settings and various categories of beach users.

The Sakumono and Mensah Guinea beaches are located in known national "hotspots" of coastal pollution. Sakumono beach is a fish-landing site for people from Sakumono village. The village is made up of mainly 


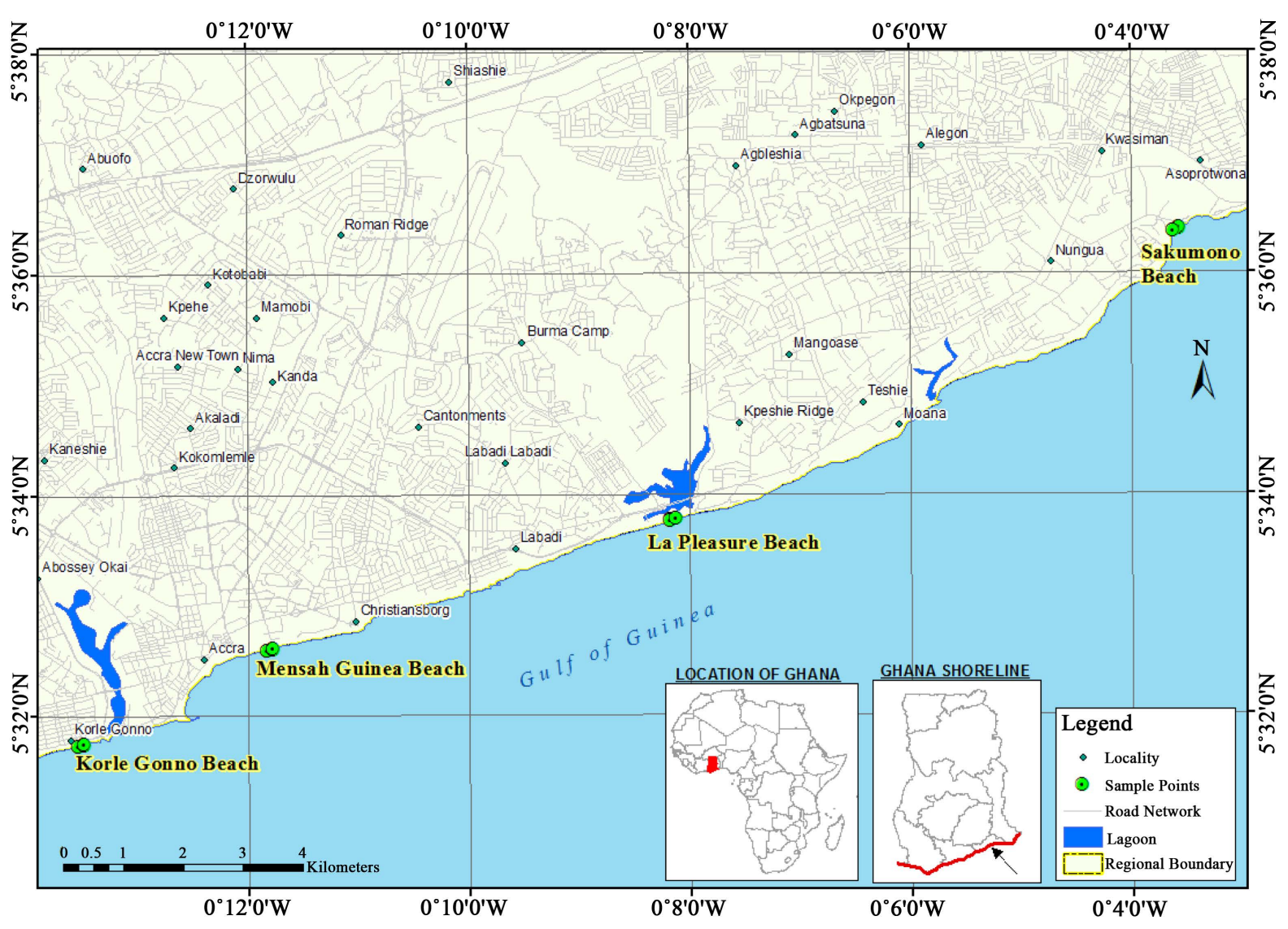

Figure 1. Map showing study sites.

small-scale artisanal fishermen, fishmongers and farmers, and is located about 8 km west of Tema on the AccraTema main coastal road. It is adjacent to Sakumono I Lagoon which is designated as a Ramsar site for its high bird biodiversity [17]. Nonetheless, the Sakumono beach has in recent times become a hub for recreational activities. It is of low to moderate slope $\left(15^{\circ}-45^{\circ}\right)$ form dune line that affords a litter trapping feature above high water level [17]. The sampling site was located within these four point -N $05^{\circ} 36.399^{\prime} \mathrm{W} 000^{\circ} 03.569$ '; $\mathrm{N}$

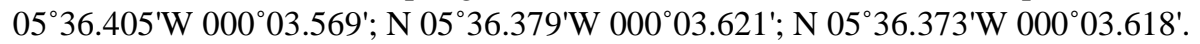

La Pleasure Beach is located off the Accra-Teshie/Nungua Road. This beach shares boundaries with 4-Star La Palm Royal and 5-Star La Pleasure Beach hotels, and is patronized throughout the week by both foreign and local tourists [20]. The beach is sandy, of a low to moderate slope. The back of the shoreline is characterized by permanent and semi-permanent structures from where beach patrons can relax and enjoy the ocean view. The sampling site was located within these four points-N 05 33.763'W 00008.175'; N $05^{\circ} 33.763^{\prime} \mathrm{W} 000^{\circ} 08.175^{\prime}$; $\mathrm{N}$ $05^{\circ} 33.781^{\prime} \mathrm{W} 000^{\circ} 08.121^{\prime} ; \mathrm{N} 05^{\circ} 33.786^{\prime} \mathrm{W} 000^{\circ} 08.123^{\prime}$.

The Mensah Guinea beach is mainly a tourist beach. It is located directly behind a major tourist market visited by people from a wide variety of economic backgrounds, both natives and visitors, in the centre of the city of Accra. Fishing activities, however, occurs rarely in this area [17]. The Mensah Guinea beach is predominantly sandy with a rock cliff at the back of the shoreline. The beach is also of low to moderate slope. The sampling

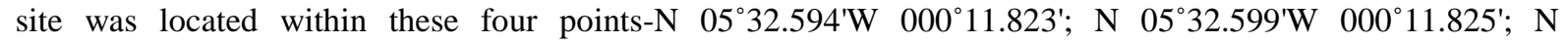
$05^{\circ} 32.609^{\prime} \mathrm{W} 000^{\circ} 11.771^{\prime}$; $\mathrm{N} 05^{\circ} 32.615^{\prime} \mathrm{W} 000^{\circ} 11.773$ '.

Korle Gonno beach is located on the western side of Accra in the densely populated community of Korle Gonno, which is well-noted nationwide for its degraded environmental conditions [19]. Beach visitors are normally local tourists who go there mostly on holidays and weekends [15]. The Korle beach is sandy and interspersed with rocky patches. Structures for enjoying the ocean view and leisure mark the back of the shoreline.

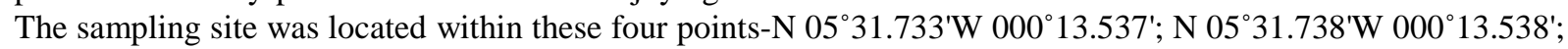
N $05^{\circ} 31.744^{\prime} \mathrm{W} 000^{\circ} 13.480^{\prime}$; N $05^{\circ} 31.752^{\prime} \mathrm{W} 000^{\circ} 13.481^{\prime}$. 


\subsection{Sampling Methodology}

A belt transect, representing a sampling area of $1000 \mathrm{~m}^{2}$ (i.e. $10 \mathrm{~m} \times 100 \mathrm{~m}$ ) was demarcated at each beach between the low tide mark and the zone of emergent vegetation for the survey. The demarcated areas ran parallel to the sea (Figure 2).

Each survey site was measured using a surveyor's measuring wheel and marked to ensure length accuracy and repeatability of successive surveys. Taking a cue from [4], semi-permanent markers were placed at the beginning and end points of the $10 \mathrm{~m} \times 100 \mathrm{~m}$ study site. In addition to establishing visual boundary markers for each site, global positioning system (GPS) coordinates (latitude and longitude) were recorded for use in GIS mapping of the study sites and database manipulation.

The litter was sorted into identifiable groups in the laboratory after which they were counted and later weighed to the nearest kilogram using an electronic scale and spring balance. Debris was further categorized as either originating from the ocean or having a land-based source based on the classification by [28]. The average number and weight of each item per week was determined. A Chi-squared test was carried out on the numbers of litter from the four beaches to establish the relationship between the types and abundance of the litter and the study site.

\subsection{Microbial Water Quality Tests}

For this study, water quality at the four study sites were carried out by testing for total coliforms, faecal coliforms and Escherichia coli. Coliforms and faecal streptococci are used as indicators of possible sewage contamination because they are commonly found in human and animal faeces.

Samples were collected from the surface of the water at a depth of $20 \mathrm{~cm}-30 \mathrm{~cm}$, two metres from the shore for each beach location. Seawater was collected on a weekly basis for sixteen weeks at all four study sites and as a quality control measure, replicate samples consisting of two samples were collected from the same depth for all the study sites.

\subsection{Social Survey}

According to [22] [23] cited by [29], people are the social drivers of the littering problem. It is therefore necessary for the people causing it to recognize this by coming to the realization that they contribute to it. Data was collected on site using face to face interviews of adults eighteen years and above. Eighteen years is the legal age for voting in Ghana, where an individual is considered an adult able to make informed decisions. Reference [29]'s combined skip interval, sample point sampling method was employed, with the next available person that walked past the sampling point at each location being asked to participate in the survey.

Surveys were conducted at all four study sites on weekdays and weekends (from10th November, 2012 to $23^{\text {rd }}$ February, 2013). The selection of respondents for the questionnaire-interviews was guided by a sampling procedure. The process involved (a) identification of the sample frame (b) determination of appropriate sample size, and (c) distribution of the selected sample size to ensure proper representation of the population.

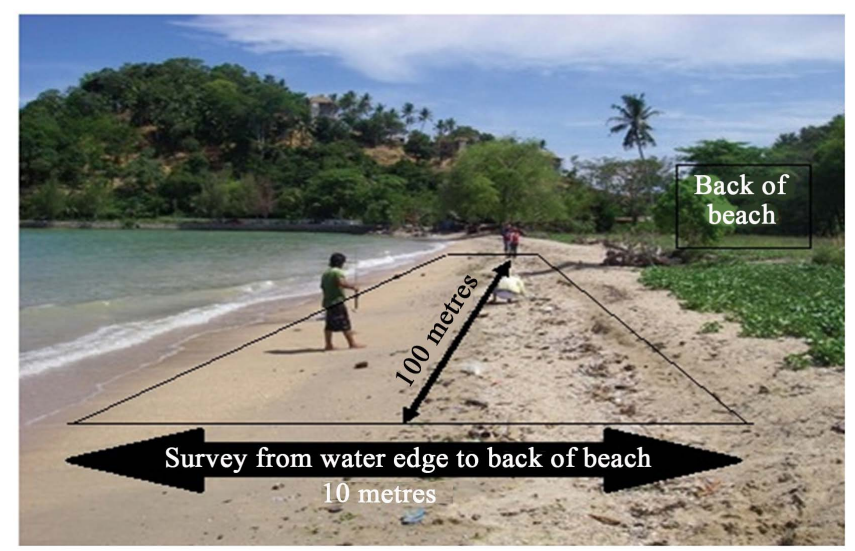

Figure 2. Schematic representation of belt transect (Source: Adapted from [27]). 
In determining the sample frame, the basic criterion adopted was that the individual should be an adult over the age of eighteen. In spite of the fact that there are few surveys related to visits in all four study sites as well as non-existent and inadequate data on visitor numbers, the sample size was calculated to be 400 from the population of Accra (three million) according to [30] using a confidence level of $95 \%$ and a confidence interval of five (5). 100 interviews were carried out at each beach location targeting individuals within the sample frame encountered on the various beach locations making a total sample size of 400 respondents.

\subsection{Stakeholders' Survey}

The views of some organizations and stakeholders were also sought using questionnaire-interviews to obtain first hand description of their opinion and understanding of the subject. Here, a motivation analysis employed by [31] which is a method of interviewing selected representatives, who provide the opinion of their organizations, was employed. The interview was designed and oriented to local stakeholders who had experience and knowledge of the beaches under study and who could provide technical details and also more strategic information. Accra Metropolitan Assembly (AMA), Tema Metro-Solid Waste Management Department, Ministry of Environment Science and Technology and, Environmental Protection Agency (EPA) were purposefully identified using core functions of these organisations which are all tailored to enhance the quality of life of the people and the protection of the environment.

\section{Results and Analysis}

\subsection{Beach Litter Survey}

A total of 18,241 items of marine debris were collected from the Sakumono, La Pleasure, Mensah Guinea and Korle Gonno beaches (see Appendix 1). Plastic bottles, black plastic bags, pure water sachets and food wrappers were the predominant litter types collected over the sixteen week period. This suggests wide spread usage of these items as well as poor disposal and a dearth of the concept of recycling of items. In terms of debris types and their sources, $93 \%$ of all debris collected was found to have originated from land with the remaining $1 \%$ and $6 \%$ originating from the ocean and general sources respectively (Table 1).

\subsection{Spatial and Temporal Abundance of the Marine Debris}

The varying debris items found accumulated on the beach sampling sites were similar to the most common items found during clean-ups conducted onshore and/or underwater: cigarettes/cigarette filters, food wrappers/containers, (plastic) bags, and (plastic) beverage bottles according to the International Coastal Cleanup report [32]. In the US, Spain and Brazil, cigarette butts have been shown to be the main source of marine debris on beaches [33]-[35]. This trend was not evident in this study, where plastic materials were found to be the most common debris type, similar to studies carried out on South African beaches [36] cited in [37] and selected beaches in Europe [38].

Sakumono beach recorded the highest number of debris items with 5154 items over the duration of the study. The lowest quantity was recorded at the Korle Gonno beach (3716 items). However, in terms of weight, debris items at Mensah Guinea beach were the heaviest $(99.91 \mathrm{~kg}$ ) followed closely by $72.58 \mathrm{~kg}$ at Korle Gonno beach. Fluctuations in debris counts were observed at all four beach sites over the study period (Figure 3). However,

Table 1. Categorization of litter types.

\begin{tabular}{|c|c|}
\hline Sources & Litter Types \\
\hline Land-Based & $\begin{array}{l}\text { Plastic bottles, straws (plastic), black plastic bags, white plastic bags, caps/lids, glass bottles, } \\
\text { pure water sachet, balloons, metal cans, cigarette packaging/ wrappers, crown corks, } \\
\text { disposable plates and spoons, khebab sticks, pieces of cigarettes, footwear pieces, clothing/textile, } \\
\text { used condoms, syringes, used diapers, toys, plastic cups, food wrappers, flip-flops, batteries, } \\
\text { charcoal, coconut husk, comb, fruit peels, kenkey peels, bags, used sanitary towels, aluminium foil, } \\
\text { newspaper/magazine pieces, bandages, umbrellas, paper drink packs, toothbrush. }\end{array}$ \\
\hline Ocean/Waterway-Based & Fishing net, rope, strapping bands, incandescent bulb, seaweed. \\
\hline General & $\begin{array}{l}\text { Nails, cardboard pieces, glass pieces, metal pieces, plastic containers, } \\
\text { Styrofoam pieces, pieces of foam, bones, car tyres. }\end{array}$ \\
\hline
\end{tabular}




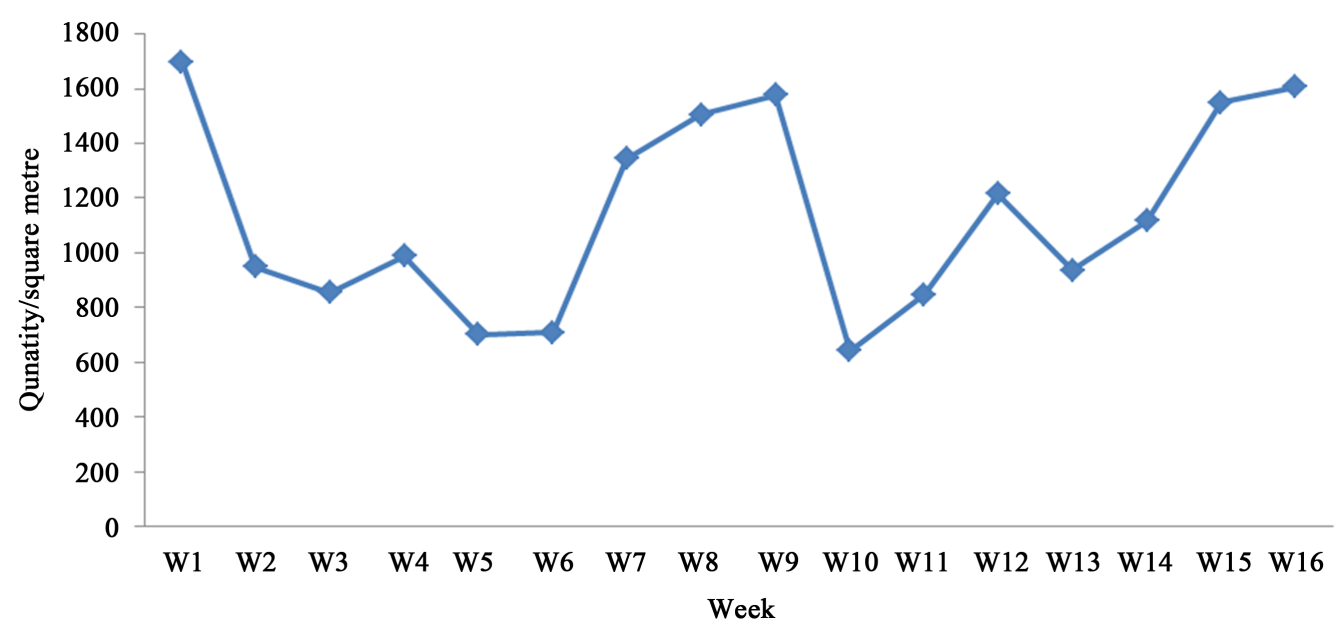

Figure 3. Overall marine debris count $\left(\mathrm{m}^{2}\right)$ over sixteen weeks.

there was no significant relationship between debris count and weight. For a value of alpha $=0.05$ indicating a 95\% confidence level the F observed was 195.45 which was larger than the F critical of 5.99 indicating with $95 \%$ confidence that the variance between groups is not due to random chance.

Seawater was observed to be highly turbid. Weeks 6, 7, 8 and 9 (December 9-30, 2013) coincided with the christmas season. This resulted in high patronage of the beaches as a result of the beach parties to mark the occasion. The sharp decline in debris count in week 10 (January 6-12, 2013) could be attributed to the uneasy calm in the country prior to the declaration of the presidential election results at the time. The gentle rise in debris quantities from week 11 through week 16 could also be attributed to high beach patronage due to the New Year festivities culminating in valentine's day celebrations (January 13 to February 17, 2013).

The results indicate a high diversity of litter collected from the study sites. The most likely explanation for this diversity is related to the uses of the selected site. The higher counts of items found at the study sites could be attributed to the fact that these sites are popular and most accessible to the local public and tourists. The litter items found at these sites, particularly plastic bottles and bags, metal cans, and pieces of glass are associated with and indicative of the activities of beach goers in accordance with the assertion of [39]. Storm water drains and sewage outfalls also transport debris into marine and coastal environments [40]. Again, with the location of the study sites in close proximity to local communities, there would be more pressure on storm water drains and sewage outfalls, which would lead to more litter being swept into drains and deposited onto the coastlines. This compares favourably to the study of [29] were low debris quantities were attributed to small population density with less pressure on these outfalls and drainage systems.

The quantities of plastics recorded at the beaches confirm the assertion of [41]-[43] that plastics are the main source of marine debris worldwide; between $60 \%$ and $80 \%$ of litter collected. The nature of wastes from human society has dramatically changed over the last 30 to 40 years due to the introduction of synthetics like plastics [26]. Non-degradable plastic materials remain predominant on Ghana's beaches reflecting the extensive use of plastics in everyday activities such as purchasing of groceries and packaging of several items and poor disposal of these items.

References [44] and [45] cited in [29] found that a large proportion of debris was ocean based. However [29] did not detect any trends with regards to where marine debris originated. In this study land based sources formed the largest proportion of debris collected (Table 1). This corresponds with the assertion in some literature that land-based sources cause approximately $80 \%$ of the marine debris found on our beaches [3] [4] [7] [8] [46] and consistent with study carried out on the West coast of the United States and main Hawaiian islands [4]. The high percentage of land-based marine debris recorded can be attributed to beach location, accessibility, status as a tourist hub and human behaviour. Again, based on the findings of [44] [45] as cited in [47] ocean based debris accounted for the least amount of debris in origin supporting the amount of ocean based debris recorded for this study. There are few major shipping routes in this region due to the presence of only one major port that operates in Tema, which may explain the low levels of ocean based debris. 


\subsection{Water Quality in Study Sites (Examining the Total and Faecal Coliforms,} and $E$. coli Levels)

Water quality analysis carried out at all the study sites over sixteen weeks revealed differing levels of Coliforms and E. coli. (Figure 4). There was no significant difference in water quality between the sites $\left(\mathrm{T}_{\text {Cal }}<1.70\right)$. The very high levels of total coliforms is not very surprising as they are widespread in nature, are both faecal and non-faecal in origin. The relatively high faecal coliform and $E$. coli levels at all the beach sites confirm the pervasive practice of disposal of sewage into the sea without any treatment in Ghana. At Sakumono beach, the high faecal coliform and $E$. coli levels could be attributed to the proximity of sewage outflow pipes which lead into the sea. Proximity to the local community which increases the likelihood of litter from recreational sources as well as the proximity to the port which increases the likelihood of accidental or illegal dumping from vessels could also be a factor.

At La Pleasure beach, a drainage system from the township and the hotels along the beach, which ends up in the sea could be a contributing factor. At Mensah Guinea beach the local community is found close to the shore and the inhabitants use the beach as a refuse dump and with some residents practicing open defecation. For primary contact, i.e. swimming, the levels of the coliform (total and faecal) at all beaches compared to WHO international standards were found to be permissible, but not desirable. For fishing and boating, the levels of coliform are within the acceptable range. Water quality results for this study is comparable to that in the Halifax harbour where raw sewage has been discharged for more than 200 years [48]. Bacterial contamination is pervasive throughout the harbour, and the waterfronts along Halifax and Dartmouth are aesthetically poor owing to particulates, floatables, and odour [49].

Bacteria count (ml) detected during sampling pooled across all the four beach sites to represent a measure of water quality. Figure 5 shows the total bacteria load recorded at the study sites.

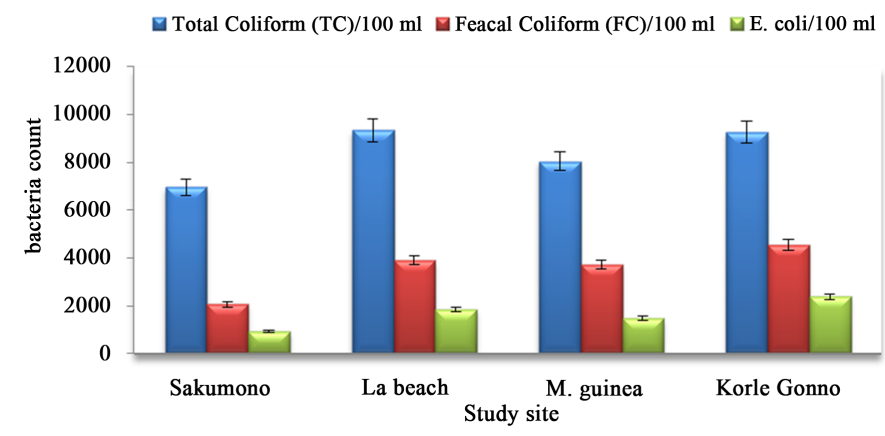

Figure 4. Mean Coliform and E. coli levels recorded at study sites over sixteen weeks.

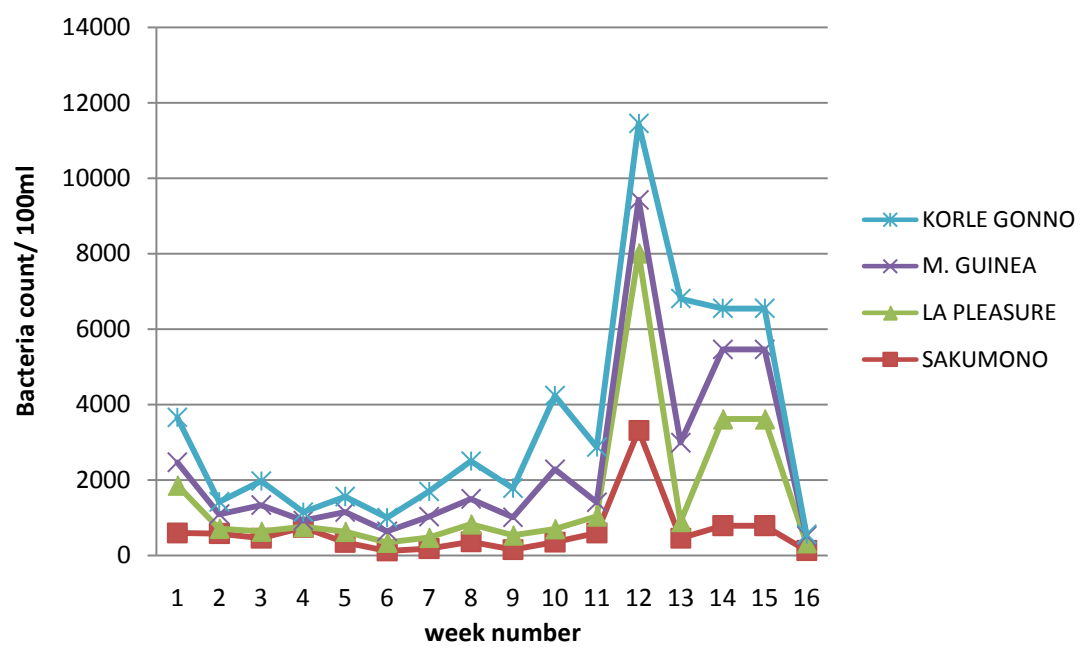

Figure 5. Total bacteria load recorded at study sites. 


\subsection{Social Survey}

\subsubsection{Characteristics of Respondents}

100 people participated in the survey at each beach location making a total of 400 people, with a response rate of $100 \%$. Some general trends are summarised in Appendix 3. The majority of participants were in the $18-25$ years and 26 - 40 years category. There was no significant difference between the number of males and females who took part in this survey. The majority of respondents (48.3\%) had other secondary occupations. $21.8 \%$ were traders followed closely by $19.3 \%$ unemployed. The majority (30\%) of the participants fell into the choose not to answer income bracket followed closely by those in the income bracket of 500 - 700 Ghana Cedis (approximately $\$ 130$ - 180) and those earning less than 400 Ghana Cedis (\$103). Most participants had attained some level of education with a majority (31.5\%) falling in the SSS/Technical/Vocational category and $25.3 \%$ being graduates.

Most (82\%) of the participants were local residents, with $55.8 \%$ participants visiting beaches occasionally. Labadi, Sakumono, La Pleasure, Mensah Guinea and Korle Gonno beaches are among the most frequently patronized beaches by participants as shown in Figure 6.

\subsubsection{Evaluation of Public Attitudes to Beach Litter}

In this study, it was assumed that survey participants were in the habit of littering. This assertion was confirmed when the majority of the participants (77.5\%) admitted to consuming food and beverages at the beach. $87.8 \%$ of respondents admitting to having left litter at least once on the beach with almost all respondents acknowledging that this was their usual habit. When asked what respondents did with litter generated at the beach, $55 \%$ admitted to leaving it directly on the beach. $34 \%$ reported they placed litter in waste bins and only $4.5 \%$ said they carried it home. $6.5 \%$ of respondents however chose not to answer.

Again, respondents were not in the habit of collecting litter they encountered on the beach nor were they willing or inclined to talk about the issue of marine debris when they encountered other people littering. The majority (66.8\%) admitted to never collecting other people's litter. $16.5 \%$ rarely collected it and $16.8 \%$ said they only sometimes did. Similarly, $56.8 \%$ of respondents admitted to speaking to those they see littering at the beach about the issue of marine debris. $24.5 \%$ rarely did so and $17.8 \%$ did so sometimes. Majority of respondents attributed the main source of litter on the beaches to beach users followed by the sea and industrial activities respectively (Figure 7).

Almost all respondents believe that Ghana's beaches are not clean and yet surprisingly they all admit to the fact that this gives them cause for concern. This development can be attributed to the fact that people have become desensitized to the litter campaigns that have been in the media for many years and may believe littering is not their problem but rather belies a belief that regulators need to control and respond to littering [22]. Again, there is strong evidence that people are more likely to litter in places where litter is already present [50]-[53]. People litter more when in an unclean environment as their social norms indicate that as the environment around them is unclean it is acceptable to litter [54] [55]. This supports my results as relatively high amounts of debris were collected during the beach survey.

When asked about issues that participants were not happy with along the beach, the majority stated poor

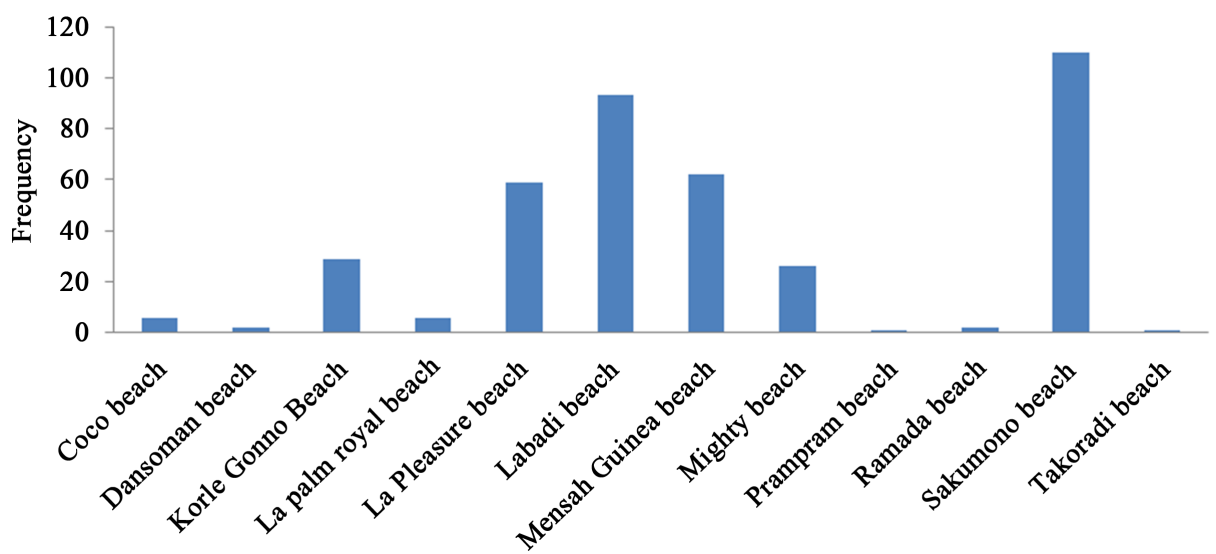

Figure 6. Beaches frequented by respondents. 


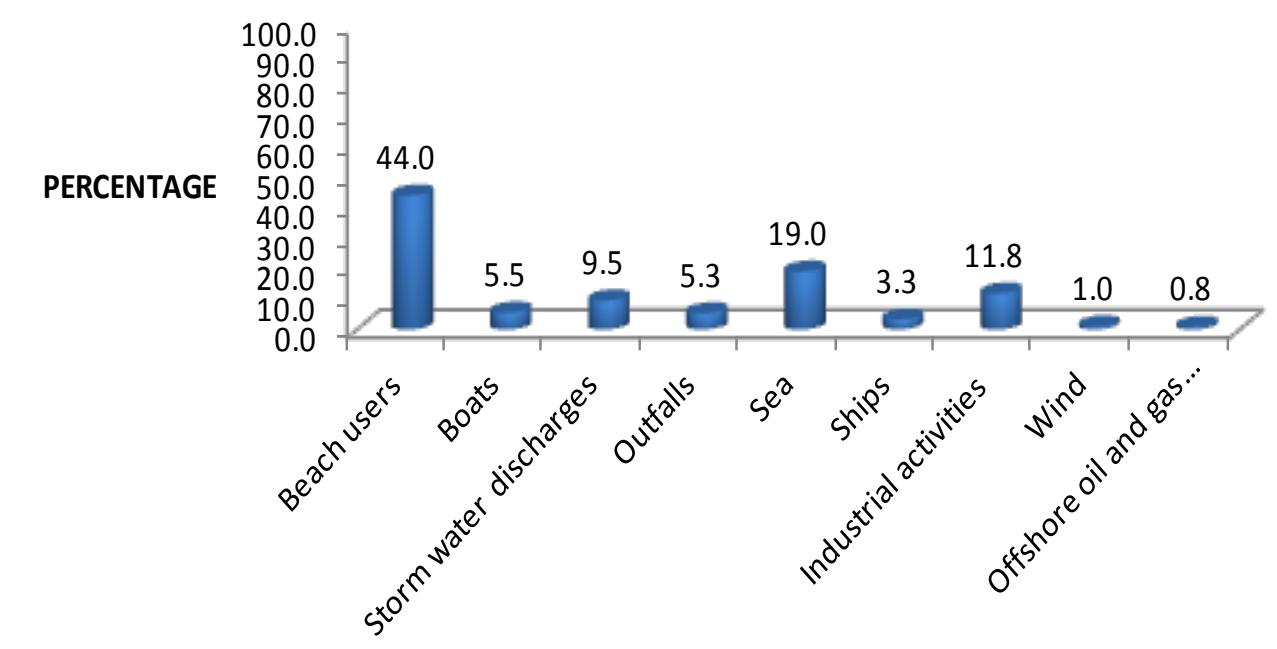

Figure 7. Main sources of marine debris.

facilities (toilets, litter bins) as their main concern followed by washed up debris. This finding is quite similar to other studies that have shown that most participants recognize marine debris and sewage related debris to be a strong beach dislike [29] [57] [58]. The results from this survey also confirms the assertion by [29] and [56] that people's actions and attitudes contribute to the issue of marine debris; evidenced in the social survey with the majority of respondents admitting to littering and the relatively high amount of debris collected during the beach survey. Participants who were beach users themselves also identified beach users as the main source of litter generation on the beach with the resultant problem of unattractive beaches.

This trend is supported in the literature where beach litter is considered to be a major problem for people who visit the beach and plays a major role in selecting a suitable beach for recreation [56] [59] [60]. Almost all participants believe that Ghana's beaches are not clean and increased education and awareness creation, provision of more litter bins and the distribution of plastic bags will help reduce litter amounts. However, applying a penalty to those that litter, providing advertisement at the beach entry about littering and beach clean ups were the least recommended, depicted in Figure 8. It can thus be inferred that littering and marine debris is a problem they acknowledge.

Responses were obtained from four local organisations that had experience and knowledge of the beaches under study. They were Accra Metropolitan Assembly (AMA), Tema Metro- Solid Waste Management Department, Ministry of Environment, Science and Technology, andthe Environmental Protection Agency (EPA).

The core functions of these organisations are all tailored to enhance the quality of life of the people and the protection of the environment. All the representatives from these organisations were of the view that marine debris is a major problem in Ghana. According to the representative from the Tema Metro- Solid waste department, this is so because:

- Marine debris pollutes the environment and mars the aesthetics of the beaches and thereby reduces patronage.

- Marine debris negatively impact on the health and safety of beach users (local and foreign)

- They also affect the ecological and biological lives of marine fishes.

Again, all the representatives were of the opinion that debris on Ghana's beaches are decreasing and assess the impact of marine debris on Ghana's beaches as high with EPA's representative citing the following reasons:

- Marine debris presence affects the nation's foreign exchange earnings to be derived from high beach patronage (by both locals and foreigners).

- Their presence also degrade the beaches and its immediate environs and to the detriment of the humans and animals.

Furthermore, the main source of debris on the beach was attributed to beach users, boats, storm water discharge, outfalls, the sea, ships, industrial activities, offshore oil and gas platforms and exploration. All representatives for the four organisations were of the view that Ghana's beaches are not clean. Each representative had suffered some kind of problem associated with litter on the beach-these included wounds, diseases, discomfort and loss of 


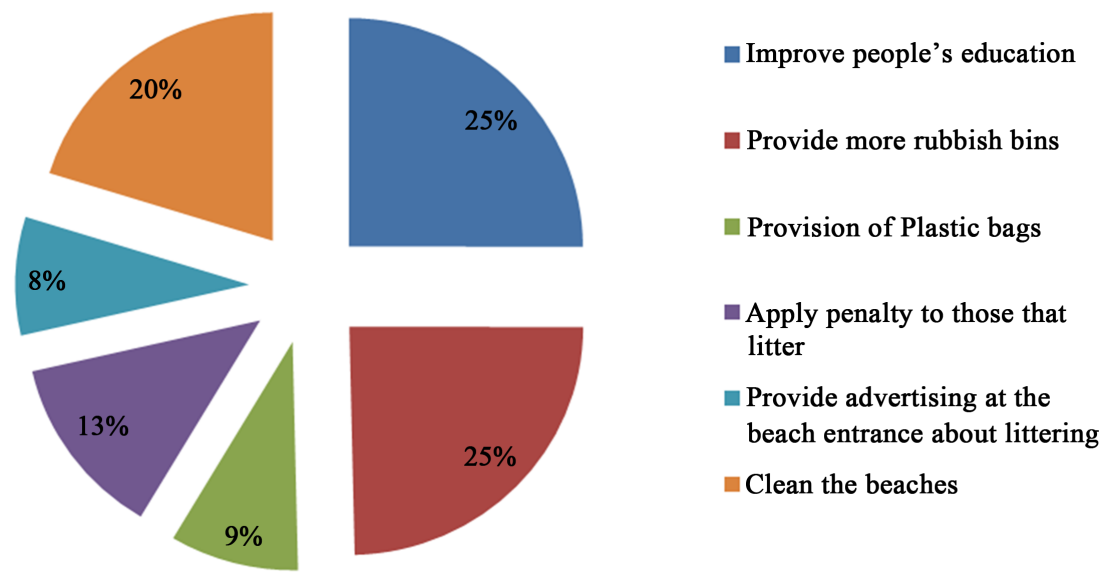

Figure 8. Management options by respondents to reduce beach litter.

revenue. Impact on human health and safety, impact on marine biota, unattractive beaches leading to low beach patronage were expressed as the main problems that marine debris can cause. Education and sensitization, provision of more litter bins, application of penalty to those that litter, the provision of advertisement at beaches about littering and beach clean ups were some of the suggestions on how to reduce litter quantities on Ghana's beaches.

\section{Conclusions and Recommendations}

The results from the study showed that plastic materials were the dominant litter item, in particular drinking water sachets, food wrappers, plastic bags, plastic bottles and containers. This reflects the extensive use of plastics in everyday activities such as purchasing of groceries, the type of packaging used for several items as well as the activities of beach users. Secondly, marine debris from land based sources remains the highest source of beach litter and ocean based sources the least. Thirdly, marine debris quantities at all four beaches were generally large and underwent weekly fluctuations with quantities peaking on occasions where beach patronage was very high and also in the event of heavy rainfall. However, Sakumono beach recorded the highest debris quantity. The results reflect the popularity of these beaches with beach goers. Mean water quality levels in all four study locations remain high in comparison to WHO guideline levels. However, Korle Gonno recorded the highest bacteria load reflecting the use of this beach as a popular site where septic sewage from homes in Accra is directly discharged into the sea in the absence of a proper sewage treatment plant.

The results of the social survey support the results of the beach survey as most survey participants admitted to littering. Respondents acknowledged the fact that marine debris is a problem and associated it with injuries, wounds and discomforts experienced at the beach. They are also aware of some beach management practices being undertaken and the organisations responsible for keeping the beaches clean.

Respondents were of the view that Ghana's beaches were generally not clean and beach users were the main source of marine debris along the beach. However, attitude towards littering remains exceedingly poor as almost all respondents acknowledge the fact that they are in the habit of littering.

Intensive education together with provision of adequate infrastructure for waste and sanitation remains key to combating the issue of marine debris on Ghana's coastlines. Packaged and targeted education should not only aim at increasing awareness but also aim at changing attitudes and behaviour. Educational and public awareness programmes using tools such as television and radio programmes, brochures, leaflets, stickers and posters should be made available and directed at reducing all litter and target users of the marine environment including local coastal communities, tourists, school teachers and students. In the short to medium term, provision of access routes to beach locations will help ensure vehicular movement to carte debris collected and will help curb the practice of burying of debris on beaches and their subsequent exposure with high tidal and wave action.

The provision of garbage collection, disposal and treatment infrastructure by the relevant institutions remain important to help curb the practice of sewage disposal directly into the sea without prior treatment. Other basic amenities such as toilets and potable water must also be provided. Water quality levels should be monitored 
regularly to avoid disease outbreaks. Where the bacteria levels are deemed life threatening, the beach should be closed off to the general public until such a time when it is safe.

Currently, beach clean ups and some degree of monitoring are being carried out on more popular beaches (urban or semi-urban beaches). Clearly, these are not yielding the needed results. Therefore adoption of the above as well as appropriate policy interventions and suitable regulations together with long term enforcement of existing ones to ensure compliance is vital to addressing marine debris along Ghana's coastlines.

Presently, data available on marine debris cover a short duration and information on the issues, types, levels and trends could be skewed. A future study carried out over a period of not less than five years will yield more results on the trend of marine debris, sea water quality and littering and give a clearer picture of where resources are best aimed. Ultimately, cooperation and coordination between the government of Ghana and other riparian countries along the Gulf of Guinea is needed to take necessary remedial measures and actions including cleaning campaigns that can help keep the coastline free from marine debris in the long term.

\section{References}

[1] Lakshmi, A. and Rajagopalan, R. (2000) Socio-Economic Implications of Coastal Zone Degradation and Their Mitigation: A Case Study from Coastal Villages in India. Ocean and Coastal Management, 43, 749-762. http://dx.doi.org/10.1016/S0964-5691(00)00057-0

[2] Tudor, D.T. and Williams, A.T. (2001) Investigation of Litter Problems in the Severn Estuary/Bristol Channel Area. Environment Agency R\&D Technical Report E1-082/TR, Bristol.

[3] NOAA (2007) Marine Debris. [Accessed 5 September 2012] http://marinedebris.noaa.gov/whatis/welcome.html

[4] Sheavly, S.B. (2007) National Marine Debris Monitoring Program: Final Program Report, Data Analysis and Summary. Prepared for U.S. Environmental Protection Agency by Ocean Conservancy, Grant Number X83053401-02, 76 p.

[5] United Nations Environment Programme (UNEP) (2009) Marine Litter: A Global Challenge. UNEP, Nairobi, 232 p.

[6] National Oceanic and Atmospheric Administration (NOAA) (2010) 2008-2009 Progress Report on the Implementation of the Marine Debris Research, Prevention, and Reduction Act. Silver Spring, MD, 70 p.

[7] World Ocean Review (2010) Living with the Oceans. MaribusgGmbH, Pickhuben, Hamburg.

[8] GESAMP (Group of Experts on the Scientific Aspects of Marine Pollution) (1991) The State of the Marine Environment. Blackwell Scientific Publications, London, 146 p.

[9] CMC (2000) Pocket Guide to Marine Debris. Center for Marine Conservation, Washington DC, 35 p.

[10] Rockefeller, D. (2008) Oceans Away. [Accessed 17 July 2012] http://www.populationeducation.org/docs/earthmatters/readingoceans_away.pdf

[11] Jambeck, J., Timothy, G.T. and Barr, C.G. (2001) A Survey of Marine Debris Management and Research. [Accessed 17 July 2012] http://www.crrc.unh.edu/marine-debris/awma_paper.pdf

[12] Government of Ghana (Ministry of Local Government and Rural Development, EPA) (June 2002) Manual for the preparation of District Waste Management Plans in Ghana. [Accessed 5 September 2012] http://gehoa.com.gh/getattachment/ecf40f58-426f-44f5-b29f-c4e24c35aeaf/01-dist-waste-planning.aspx

[13] Amlalo, D.S. (2007) The Protection, Management and Development of the Marine and Coastal Environment of Ghana. http://www.Figure.net/pub/figpub/pub36/chapters/chapter 10.pdf

[14] UNEP (1990) The Problem of Persistent Plastics and Marine Debris in the Oceans. UNEP Regional Seas Reports and Studies No. 114.

[15] Topping, P., Eade, A. and Eaton, P. (1994) Marine Plastic Debris Research in Canada. Paper presented at the 3rd International Conference on Marine Debris, Miami, Florida, May 1994. Marine Environment Division, Canada. PMCid:PMC2142715

[16] Hoagland, P. and Kitte-Powell, H.L. (1997) Characterisation and Mitigation of Marine Debris in the Gulf of Maine. A report prepared for the US Gulf of Maine Association. Contract No. GM 97-13. Woods Hole Research Consortium. 36 p.

[17] Nunoo, F.K.E. and Quayson, E. (2003) Towards Management of Litter Accumulation—Case Study of Two Beaches in Accra, Ghana. Journal of the Ghana Science Association, 5, 145-155.

[18] CMC (1997) International Cleanup 1996-2000 Data, 4 p.

[19] Nunoo, F.K.E. and Evans, S.M. (1997) The By-Catch Problem of the Commercial Shrimp Fishery in Ghana. In: Evans, S.M., Vanderpuye, C.J. and Armah, A.K., Eds., The Coastal Zone of West Africa: Problems and Management, Penshaw Press, UK, 187-196. 
[20] Tsagbey, S.A., Mensah, A.M. and Nunoo, F.K.E. (2009) Influence of Tourist Pressure on Beach Litter and Microbial Quality: Case Study of Two Beach Resorts in Ghana. West African Journal of Applied Ecology, 15, 13-23.

[21] Rees, G. and Pond, K. (1997) Marine Litter Monitoring Programmes-A Review of Methods with Special Reference to National Surveys. Marine Pollution Bulletin, 30, 103-108. http://dx.doi.org/10.1016/0025-326X(94)00192-C

[22] Arafat, H.A., Al-Khatib, I.A., Daoud, R. and Shwahneh, H. (2007) Influence of Socio Economic Factors on Street Litter Generation in the Middle East: Effects of Education, Level, Age and Type of Residence. Waste Management and Research, 25, 363-370. http://dx.doi.org/10.1177/0734242X07076942

[23] Bator, R.J. (2011) Who Gives a Hoot? Intercept Surveys of Litters and Disposers. Environment and Behavior, 43, 295315. http://dx.doi.org/10.1177/0013916509356884

[24] UNEP/GPA (2006) Protecting Coastal and Marine Environment from Impacts of Land-Based Activities: A Guide for National Action. Trinidad and Tobago National Programme of Action for the Protection of the Coastal and Marine Environment from Land-Based Sources and Activities 2008-2013.

[25] Coe, J.M. and Rodgers, D.B. (1997) Marine Debris: Sources, Impacts and Solutions. Springer-Verlag, New York, 432 p. http://dx.doi.org/10.1007/978-1-4613-8486-1

[26] Sheavly, S.B. (2005) Marine Debris-An Overview of a Critical Issue for Our Oceans. 6th Meeting of the UN Open-Ended Informal Consultative Processes on Oceans \& the Law of the Sea, New York, 6-10 June 2005, 7 p.

[27] Cheshire, A.C., Adler, E., Barbière, J., Cohen, Y., Evans, S., Jarayabhand, S., Jeftic, L., Jung, R.T., Kinsey, S., Kusui, E.T., Lavine, I., Manyara, P., Oosterbaan, L., Pereira, M.A., Sheavly, S., Tkalin, A., Varadarajan, S., Wenneker, B. and Westphalen, G. (2009) UNEP/IOC Guidelines on Survey and Monitoring of Marine Litter. UNEP Regional Seas Reports and Studies No. 186, IOC Technical Series No. 83, 120 p.

[28] Barr, C. (2000) Marine Debris Monitoring and Data Collection Activities Conducted by the Center for Marine Conservation. The International Marine Debris Conference on Derelict Fishing Gear and the Ocean Environment, Honolulu, 6-11 August 2000, 116-129.

[29] Slavin, M.C. (2011) Types and Sources of Marine Debris in Northern Tasmania. B.Sc. Thesis, Central Queensland University, Queensland.

[30] Ghana Statistical Service (2012) 2010 Population and Housing Census. Summary Report of Final Results.

[31] Roca, E. and Villares, M. (2008) Public Perceptions for Evaluating Beach Quality in Urban and Semi-Natural Environments. Ocean \& Coastal Management, 51, 314-329. http://dx.doi.org/10.1016/j.ocecoaman.2007.09.001

[32] Ocean Conservancy (2008) 2007 International Coastal Clean-Up Results. Washington DC, 56 p.

[33] Moore, C.J., Moore, S.L., Leecaster, M.K. and Weisberg, S.B. (2001) A Comparison of Plastic and Plankton in the North Pacific Central Gyre. Marine Pollution Bulletin, 42, 1297-1300. http://dx.doi.org/10.1016/S0025-326X(01)00114-X

[34] Martinez-Ribes, L., Bastertetxea, G., Palmer, M. and Trinore, J. (2007) Origin and Abundance of Beach Debris in the Balearic Islands. Scientia Marina, 71, 305-314.

[35] Oigman-Pszczol, S.S. and Creed, J.C. (2007) Quantification and Classification of Marine Litter on Beaches along Armação dos Búzios, Rio de Janeiro, Brazil. Journal of Coastal Research, 23, 421-428. http://dx.doi.org/10.2112/1551-5036(2007)23[421:QACOML]2.0.CO;2

[36] Ryan, P.G., Moore, C.J., van Franeker, J.A. and Moloney, C.L. (2009) Monitoring the Abundance of Plastic Debris in the Marine Environment. Philosophical Transactions of the Royal Society B, 364, 1999-2012. http://dx.doi.org/10.1098/rstb.2008.0207

[37] STAP (2011) Marine Debris: Defining a Global Environmental Challenge. A STAP Information Document. Global Environment Facility, Washington DC.

[38] OSPAR (2007) OSPAR Pilot Project on Monitoring Marine Beach Litter: Monitoring of Marine Litter on Beaches in the OSPAR Region. OSPAR Commission, London.

[39] Al-Najjar, T. and Al-Shiyab, A. (2011) Marine Litter at (Al-Ghandoor Area) the Most Northern Part of the Jordanian Coast of the Gulf of Aqaba, Red Sea. Natural Science, 3, 921-926. http://dx.doi.org/10.4236/ns.2011.311118

[40] Williams, A.T. and Simmons, S.L. (1997) Estuarine Litter at the River/Beach Interface in the Bristol Channel, United Kingdom. Journal of Coastal Research, 13, 1159-1165.

[41] Derraik, J.G.B. (2002) The Pollution of the Marine Environment by Plastic Debris: A Review. Marine Pollution Bulletin, 44, 842-852. http://dx.doi.org/10.1016/S0025-326X(02)00220-5

[42] Allsopp, M., Walters, A., Santillo, D. and Johnston, P. (2006) Plastic Debris in the World's Oceans. Greenpeace.

[43] STAP (2011) Marine Debris as a Global Environmental Problem: Introducing a Solutions Based Framework Focused on Plastic. A STAP Information Document. Global Environment Facility, Washington DC. 
[44] Slater, J. (1991) Flotsam and Jetsam. Marine Debris Bulletin 1, Department of Parks, Wildlife and Heritage, Tasmania.

[45] Slater, J. (1992) The Incidence of Marine Debris in the South West of the World Heritage Area. Tasmanian Naturalist, 25, 32-35.

[46] United States Environmental Protection Agency (2012) Water: Marine Debris. Environmental Protection Agency, Office of Water, Washington DC.

[47] Gregory, M.R. and Ryan, P.G. (1997) Pelagic Plastics and Other Seaborne Persistent Synthetic Debris: A Review of Southern Hemisphere Perspectives. Prepared for AB 259 (Krekorian), AB 820 (Karnette), and AB 904 (Feuer) by the Algalita Marine Research Foundation. http://dx.doi.org/10.1007/978-1-4613-8486-1_6

[48] Buckley, D.E. and Winters, G.V. (1992) Geochemical Characteristics of Contaminated Surficial Sediments in Halifax Harbour: Impact of Waste Discharge. Canadian Journal of Earth Sciences, 29, 2617-2639. http://dx.doi.org/10.1139/e92-208

[49] Walker, T.R., Grant, J. and Archambault, M. (2006) Accumulation of Marine Debris on an Intertidal Beach in an Urban Park (Halifax Harbour, Nova Scotia). Water Quality Resources Journal of Canada, 41, 256-262.

[50] Heberlein, T.A. (1971) Moral Norms, Threatened Sanctions and Littering Behaviour. Unpublished Doctoral Dissertation, University of Wisconsin, Madison.

[51] Geller, E.S., Brasted, W.W. and Mann, M. (1980) Waste Receptacle Designs and Interventions for Litter Control. Journal of Environmental Systems, 9, 145-160. http://dx.doi.org/10.2190/5P46-8H2N-41JR-C2EJ

[52] Cialdini, R.B., Kallgren, C.A. and Reno, R.R. (1991) A Focus Theory of Normative Conduct: A Theoretical Refinement and Re-Evaluation of the Role of Norms in Human Behavior. Advances in Experimental Social Psychology, 24, 201-234. http://dx.doi.org/10.1016/S0065-2601(08)60330-5

[53] Al-Khatib, I.A., Arafat, H.A., Daoud, R. and Shwahneh, H. (2009) Enhanced Solid Waste Management and Understanding the Effects of Gender, Income Marital Status and Religious Convictions on Attitudes and Practices Related to Street Littering in Nablus-Palestinian Territory. Waste Management, 29, 499-455. http://dx.doi.org/10.1016/j.wasman.2008.02.004

[54] Cialdini, R.B., Reno, R.R. and Kallgren, C.A. (1990) A Focus Theory of Normative Conduct: Recycling the Concept of Norms to Reduce Littering in Public Places. Journal of Personality and Social Psychology, 58, 1015-1026. http://dx.doi.org/10.1037/0022-3514.58.6.1015

[55] Sibley, C.G. and Liu, J.H. (2003) Differentiating Active and Passive Littering: A Two-Stage Process Model of Littering Behaviour in Public Spaces. Environment and Behavior, 35, 415-433. http://dx.doi.org/10.1177/0013916503035003006

[56] Santos, I.R., Friedrich, A.C., Wallner-Kersanach, M. and Fillmann, G. (2005) Influence of Socio-Economic Characteristics of Beach Users on Litter Generation. Ocean and Coastal Management, 48, 742-752. http://dx.doi.org/10.1016/j.ocecoaman.2005.08.006

[57] Williams, A.T., Pond, K. and Phillip, R. (2000) Aesthetic Aspects, Monitoring Bathing Waters. In: Bartram, J. and Rees, G., Eds., Monitoring Bathing Waters, E \& FN Spon, London, 283-311.

[58] Tudor, D.T. and Williams, A.T. (2003) Public Perception and Opinion of Visible Beach Aesthetic Pollution: The Utilisation of Photography. Journal of Coastal Research, 19, 1104-1115.

[59] Nelson, C. (1998) Public Perception and Coastal Pollution at Identified Beaches in South Wales. PhD Thesis, Open University, Milton Keynes, 335 p.

[60] Tudor, D.T. and Williams, A.T. (2008) Important Aspects of Beach Pollution to Managers: Wales and the Bristol Channel, UK. Journal of Coastal Research, 24, 735-745. http://dx.doi.org/10.2112/06-0727.1 
Appendices

Appendix 1. Relative composition of litter sampled from the four study sites.

\begin{tabular}{|c|c|c|c|c|c|}
\hline NO. & TYPES OF LITTER & TOTAL WT. & $\%$ WT & TOTAL NO. & $\%$ NO. \\
\hline 1 & Plastic Bottles & 11.712 & 3.94 & 1348 & 7.39 \\
\hline 2 & Straws (plastic) & 0.123 & 0.04 & 580 & 3.18 \\
\hline 3 & Black plastic bags & 39.41 & 13.24 & 2290 & 12.55 \\
\hline 4 & White plastic bags & 7.038 & 2.36 & 1031 & 5.65 \\
\hline 5 & Caps, lids & 0.139 & 0.05 & 733 & 4.02 \\
\hline 6 & Glass bottles & 12.37 & 4.16 & 210 & 1.15 \\
\hline 7 & Pure water sachet & 24.713 & 8.30 & 2606 & 14.29 \\
\hline 8 & Balloons & 0.002 & 0.00 & 12 & 0.07 \\
\hline 9 & Metal cans & 12.898 & 4.33 & 500 & 2.74 \\
\hline 10 & Nails & 0.002 & 0.00 & 4 & 0.02 \\
\hline 11 & Cigarette packaging/ wrappers & 0.322 & 0.11 & 335 & 1.84 \\
\hline 12 & Crown corks & 0.596 & 0.20 & 447 & 2.45 \\
\hline 13 & Cardboard pieces & 0.543 & 0.18 & 178 & 0.98 \\
\hline 14 & Glass pieces & 2.395 & 0.80 & 44 & 0.24 \\
\hline 15 & Disposable plates and spoons & 2.748 & 0.92 & 769 & 4.22 \\
\hline 16 & Khebab sticks & 0.631 & 0.21 & 289 & 1.58 \\
\hline 17 & Metal pieces & 9.249 & 3.11 & 171 & 0.94 \\
\hline 18 & Pieces of cigarettes & 0.064 & 0.02 & 286 & 1.57 \\
\hline 19 & Footwear pieces & 1.474 & 0.50 & 76 & 0.42 \\
\hline 20 & Clothing/textile & 15.539 & 5.22 & 409 & 2.24 \\
\hline 21 & Used condoms & 0.003 & 0.00 & 44 & 0.24 \\
\hline 22 & Syringes & 0.011 & 0.00 & 8 & 0.04 \\
\hline 23 & Used diapers & 3.643 & 1.22 & 53 & 0.29 \\
\hline 24 & Fishing net & 3.864 & 1.30 & 17 & 0.09 \\
\hline 25 & Rope & 3.729 & 1.25 & 54 & 0.30 \\
\hline 26 & Strapping bands & 0.043 & 0.01 & 38 & 0.21 \\
\hline 27 & Car tyres & 12.901 & 4.34 & 12 & 0.07 \\
\hline 28 & Toys & 33.25 & 11.17 & 34 & 0.19 \\
\hline 29 & Plastic cups & 3.732 & 1.25 & 634 & 3.48 \\
\hline 30 & Food wrappers & 11.817 & 3.97 & 2349 & 12.88 \\
\hline 31 & Flip-flops (Rubber slippers) & 1.34 & 0.45 & 235 & 1.29 \\
\hline 32 & Batteries & 0.066 & 0.02 & 25 & 0.14 \\
\hline 33 & Charcoal & 0.63 & 0.21 & 176 & 0.96 \\
\hline 34 & Coconut husk & 8.617 & 2.90 & 141 & 0.77 \\
\hline
\end{tabular}




\section{Continued}

\begin{tabular}{|c|c|c|c|c|c|}
\hline 35 & Bones & 3.693 & 1.24 & 47 & 0.26 \\
\hline 36 & Comb & 0.004 & 0.00 & 6 & 0.03 \\
\hline 37 & Fruit peels & 0.789 & 0.27 & 203 & 1.11 \\
\hline 38 & Kenkey peels & 2.354 & 0.79 & 193 & 1.06 \\
\hline 39 & Styrofoam pieces & 0.755 & 0.25 & 143 & 0.78 \\
\hline 40 & Bags & 24.292 & 8.16 & 24 & 0.13 \\
\hline 41 & Used sanitary towels & 27.749 & 9.32 & 34 & 0.19 \\
\hline 42 & Aluminium foil & 0.038 & 0.01 & 33 & 0.18 \\
\hline 43 & Newspaper/Magazine pieces & 2.056 & 0.69 & 542 & 2.97 \\
\hline 44 & Bandages & 0.05 & 0.02 & 26 & 0.14 \\
\hline 45 & Umbrellas & 0.025 & 0.01 & 1 & 0.01 \\
\hline 46 & Paper drink packs & 4.361 & 1.47 & 316 & 1.73 \\
\hline 47 & Pieces of foam & 0.573 & 0.19 & 95 & 0.52 \\
\hline 48 & Plastic containers & 4.571 & 1.54 & 381 & 2.09 \\
\hline 49 & Incandescent bulb & 0.605 & 0.20 & 42 & 0.23 \\
\hline 50 & Toothbrush & 0.001 & 0.00 & 4 & 0.02 \\
\hline \multirow[t]{4}{*}{51} & Seaweed & 0.061 & 0.02 & 13 & 0.07 \\
\hline & TOTAL & 297.59 & 100.00 & 18241 & 100.00 \\
\hline & MEAN & 5.835 & & 357.667 & \\
\hline & VARIANCE & 84.932 & & $351,108.187$ & \\
\hline
\end{tabular}

Appendix 2. Summary of debris weight and count collected from sampled beaches over sixteen weeks.

\begin{tabular}{|c|c|c|}
\hline Beach & Weight (kg/1000 m²) & Total number (items/1000 $\mathrm{m}^{2}$ ) \\
\hline Sakumono & 67.21 & 5154 \\
\hline La Pleasure & 57.88 & 4423 \\
\hline Mensah Guinea & 99.91 & 4948 \\
\hline Korle Gonno & 72.58 & 3716 \\
\hline
\end{tabular}

Appendix 3. Summary of the demographic variables collected for the social perception survey.

\begin{tabular}{|c|c|c|c|c|}
\hline Demographic Variable & Description & Categories & Frequency & Percentage (\%) \\
\hline \multirow{4}{*}{ Study site } & \multirow{4}{*}{$\begin{array}{l}\text { Beach locations where } \\
\text { survey was carried out. }\end{array}$} & Sakumono beach & 100 & 25.0 \\
\hline & & La pleasure beach & 100 & 25.0 \\
\hline & & Mensah Guinea beach & 100 & 25.0 \\
\hline & & Korle Gonno beach & 100 & 25.0 \\
\hline \multirow{4}{*}{ Residency } & \multirow{4}{*}{$\begin{array}{l}\text { Place of residency } \\
\text { at the time of survey. }\end{array}$} & Local resident & 328 & 82.0 \\
\hline & & Ghanaian tourist & 10 & 2.50 \\
\hline & & International tourist & 59 & 14.8 \\
\hline & & Other (Expatriate) & 3 & 0.8 \\
\hline
\end{tabular}




\section{Continued}

\begin{tabular}{|c|c|c|c|c|}
\hline \multirow{3}{*}{ Age } & \multirow{3}{*}{$\begin{array}{c}\text { Age of respondent. Age } \\
\text { category with no response } \\
\text { was eliminated from analysis. }\end{array}$} & 18 - 25 years & 149 & 37.3 \\
\hline & & $26-40$ years & 180 & 45.0 \\
\hline & & 41 - 65 years & 71 & 17.8 \\
\hline \multirow{3}{*}{ Gender } & \multirow{3}{*}{$\begin{array}{l}\text { Asked respondents their gender; } \\
\text { male, female. }\end{array}$} & Female & 189 & 47.3 \\
\hline & & Male & 211 & 52.8 \\
\hline & & Fisherman & 43 & 10.8 \\
\hline \multirow{3}{*}{ Occupation } & \multirow{3}{*}{ Primary occupation of respondent } & Trader & 87 & 21.8 \\
\hline & & Unemployed & 77 & 19.3 \\
\hline & & Other & 193 & 48.3 \\
\hline \multirow{5}{*}{ Income } & \multirow{5}{*}{ Average monthly income in GHS } & Less than GHS 400 & 97 & 24.3 \\
\hline & & GHS $500-700$ & 113 & 28.3 \\
\hline & & GHS $800-1000$ & 38 & 9.5 \\
\hline & & GHS $1000+$ & 32 & 8.0 \\
\hline & & Choose not to answer & 120 & 30.0 \\
\hline \multirow{7}{*}{ Education } & \multirow{7}{*}{ Highest level of education attained } & Illiterate & 25 & 6.3 \\
\hline & & Primary & 70 & 17.5 \\
\hline & & JSS/Middle school & 54 & 13.5 \\
\hline & & SSS/Technical/vocational & 126 & 31.5 \\
\hline & & Graduate & 101 & 25.3 \\
\hline & & Postgraduate & 17 & 4.3 \\
\hline & & choose not to answer & 7 & 1.8 \\
\hline \multirow{5}{*}{ Beach visits } & \multirow{5}{*}{ How often respondents visit the beach } & Daily & 98 & 24.5 \\
\hline & & Weekly & 52 & 13.0 \\
\hline & & Monthly & 25 & 6.3 \\
\hline & & Yearly & 2 & 0.5 \\
\hline & & Occasionally & 223 & 55.8 \\
\hline
\end{tabular}

